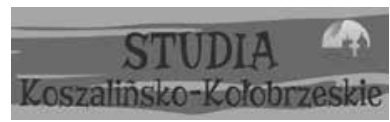

2015 nr 22

DOI: $10.18276 /$ skk.2015.22-03

Beate Kowalski ${ }^{1}$

\title{
MEANING AND FUNCTION OF THE SIGN OF JONAH IN MATTHEW 12:38-42 AND 16:1-4
}

\section{Introduction}

\section{Question}

Which metaphors and comparisons did Matthew use to express hope for resurrection? The religious and cultural contexts of his theological thoughts are explored in the first part of this volume. This second part deals with particular texts that are not limited to the resurrection narratives in Matt 28. In what follows we will have a close look at Matthew's understanding of Jonah's sign. What did he mean with the sign of Jonah? Did Matthew understand it in terms of resurrection? And if so, did he follow examples of the past? Why did he mention the sign of Jonah in this particular context of his composition?

\section{State of research}

It is worthwhile to investigate the issue again, in particular as the sign of Jonah is one of the open questions and desiderates left open by modern exegetes. Modern publications are rare. G.M. Landes and K. Huber ${ }^{2}$ argue that the text is coherent and that two interpretations of Jonah's sign are discussed among scholars. Both point to the different possibilities of interpretation without solving the enigma. Even recent commentaries ${ }^{3}$ refer to the

1 Prof. dr Beate Kowalski, Lehrstuhl für Exegese und Theologie des NT, Institut für Katholische Theologie, Fakultät 14: Humanwissenschaften und Theologie Technische Universität Dortmund, Emil-Figge-Str. 50, D-44227 Dortmund, e-mail: Beate.Kowalski@tu-dortmund.de.

2 Most recent publications are A.K.M. Adam, The Sign of Jonah: A Fish-Eye View, in Semeia 51 (1990) 177-191; S. Chow, The Sign of Jonah Reconsidered: A Study of its Meaning in the Gospel Traditions (ConBNT, 27), Stockholm, Almqvist \& Wiksell, 1995; E. Fales, Taming the Tehom: The Sign of Jonah in Matthew, in R.M. Price J.J. Lowder (eds.), The Empty Tomb: Jesus Beyond the Grave, Amherst, N.Y., Prometheus Books, 2005, pp. 307-348. Fales analyzes the difference between the three days and nights and the third day of resurrection in Matthew's passion narrative; D. Rudman, The Sign of Jonah, in ExpTim 115 (2004) 325-328.G.M. Landes, Jonah in Luke: The Hebrew Bible Background to the Interpretation of the 'Sign of Jonah'Pericope in Luke 11.29-32, in R.D. Weis - D.M. Carr (eds.), A Gift of God in Due Season: Essays on Scripture and Community in Honor of James A. Sanders (JSOTSup, 225), Sheffield, JSOT-Press, 1996, pp. 133-163; K. Huber, ,, Zeichen des Jona “ und „,mehr als Jona “: Die Gestalt des Jona im Neuen Testament und ihr Beitrag zur bibeltheologischen Fragestellung, in PzB 7,2 (1998) pp. 77-94; R.K. Soulen, The Sign of Jonah, in ThTo 65,3(2008) 331-343.

3 Cf. for example P. Fiedler, Das Matthäusevangelium (ThKNT, 1), Stuttgart, Kohlhammer 2006. 
classical writers on the topic: A. Vögtle's publication from the year $1971^{4}$ or J. Jeremias' article $^{5}$ in the ThWNT from 1938 are often quoted 6 . The issues discussed among scholars mostly comprise the methodologies of literary criticism, redaction criticism ${ }^{7}$ and traditional criticism ${ }^{8}$. Recent articles ${ }^{9}$ on the issue summarise the problems but do neither offer an own approach nor an appropriate solution. The main question of this contribution is if the sign of Jonah is connected with the idea of resurrection.

\section{Methodology}

In order to find appropriate answers to the question if the sign of Jonah is connected with the idea of resurrection we will have a closer look at the theology of the book of Jonah and its reception in early Judaism before analysing the text passages in Matthew's Gospel. Furthermore, we examine the understanding of Jonah in the NT writings in general and then more specific in Matthew. After comparing Matt 12:38-42 and 16:1-4 with its Markan Vorlage we will analyse both texts in detail. In particular, we will explore the context and composition of both text segments in order to understand the theological argumentation. Furthermore, we will explore the texts itself with special regard to the following aspects: addressees (respective opponents), motivation of their demand for a sign, kind of sign, the understanding of $\sigma \eta \mu \varepsilon$ ĩov in Matthew, and Jesus' interpretation of Jonah's sign in Matthew. Therefore, the meaning of the duration of three days and three nights in the Bible will be most important.

\section{Jonah in the Old Testament}

Jonah is one of the Twelve Prophets. In the Hebrew tradition with its chronological order of the prophetic books it stands between Obadiah and Micah, all prophets of the $8^{\text {th }}$ century. The Minor Prophets are thematically arranged in the LXX. Jonah is the first of two prophets (Nahum is the second) pronouncing judgment on the Gentiles.

This little booklet has a special position within the prophetic writings insofar as it is a prophetic narrative with only one prophetic word (3:4). The name of the prophet is programmatic: Jonah means "dove" or "oppressiveness" which characterises the lack of

4 Cf. A. Vögtle, Der Spruch vom Jonazeichen, in: Id., Evangelium und die Evangelien. Beiträge zur Evangelienforschung (KBANT), Düsseldorf, Patmos, 1971, pp. 103-136.

5 J. Jeremias, 'I $\omega v \tilde{\alpha} \varsigma$, in ThWNT 3 (1938) pp. 410-413.

6 Cf. further older publications R.A. Edwards, The Sign of Jonah in the Theology of the Evangelists and $Q$ (SBT, 2/18), London, SCM, 1971; G. Schmitt, Das Zeichen des Jona, in ZNW 69 (1978) 123-129; P. Seidelin, Das Jonaszeichen, in ST 5 (1951) pp. 119-131.

7 Cf. A. Sand, Das Evangelium nach Matthäus (RNT), Regensburg, Pustet, 1986, pp.265-267. He argues for the later redaction of vv. 41-42 (p. 265). Consequently he interprets the sign of Jonah as a reflection of the post-Eastern church.

8 Cf. A. Fuchs, Das Zeichen des Jona: Vom Rückfall, in SNTSU, 19 (1994) 131-160 and J.L. Reed, The Sign of Jonah (Q 11:29-32) and other Epic Traditions in Q, in E.A. Castelli - H. Taussig (Eds.), Reimaging Christian Origins, Valley Forge, Pa., Trinity Press, 1996, pp. 130-143.

9 Cf. K. Huber, Zeichen, pp. 77-94. 
direction. The prophet portrays Israel's senselessness and lack of loyalty in flitting back and forth between Assyria and Egypt (Hos 7:11-12; 11:11).

The book of Jonah has a clear twofold parallel structure with an additional element in the second part:

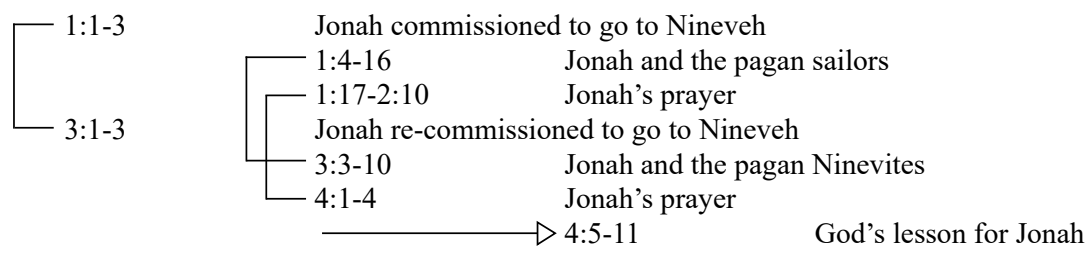

Illustration 1: Composition of the Book of Jonah.

The narrative works with contrasts, parallel structures, keywords, repetitions, parody, and a turning point. The prophetic commission in 1:1 and 3:1 "Now the word of the LORD came to Jonah the son of Amittai, saying") demands from Jonah preaching against Nineveh because of the wickedness of the inhabitants. Instead, Jonah found a ship going to Tarshish, a place which is similar to the original destination of Jonah. According to Isa 66:19 Tarshish is described as a place where YHWH is unknown: "And from them I will send survivors to the nations, to Tarshish, Put, and Lud, who draw the bow, to Tubal and Javan, to the coastlands afar off, that have not heard my fame or seen my glory; and they shall declare my glory among the nations." Only after calling him a second time Jonah obeys God. The inhabitants of Nineveh came to believe in God and proclaimed a fasting. Their key question is: "Who knows, God may yet repent and turn from his fierce anger, so that we perish not?" (3:9). This question is put to Israel.

It is part of the bitter parody and the turning point of the story that God asks the prophet if he is able to change his mind (4:11). The book leaves the reader with an open end and many questions: Can Jonah change his mind about God? And if God can: We can do! Can Jonah move away from his anger? The main question is not: Can God change? But: Can Jonah change? What about the reader's image of God? Can they believe that God is merciful towards everybody? Can they give a last chance not only to themselves but also to many others who might not deserve his mercy in their eyes?

In the Hebrew Bible Jonah includes many messages for Israel: Israel is told how quickly pagan people can convert to the God of Israel and how God comes to the prophet. Israel is told how great God's mercy is with the Gentiles. There is a tension in the Twelve-Prophets book between the salvation of Israel and the nations.

In summary, the book of Jonah is a lesson on the image of God and the conversion of the Gentiles. The image of a changing God serves as a model for the prophetic announcement of Israel's opening towards the Gentiles. The alternative between an exclusive merciful or righteous God is contradicted by Jonah's theology. His image of God is full of surprises and breaks up the classical fixed theological reflection ${ }^{10}$. Jonah criticizes the idea of an available God. The book contains extensive theological criticism by con-

10 C. Ruhe-Glatt, Das Zeichen des Jona, in $P z B$ 10(2001) pp. 41-56, p. 54. 
demning doctrinal theology and its application to daily life. It exceeds all expectations towards God. The truth of God cannot be fixed in institutions or language. The only problem is the prophet Jonah struggling with this new insight.

The little story of the fish appointed by God to swallow Jonah (1:17-2:10) including Jonah's pious thanksgiving prayer is part of the narrator's irony: Jonah is going down into the deepest depth. He is close to death but rescued by God's word (2:11). The ideas of death and rescue are crucial in the Jonah story. But rescue did not yet point to the idea of resurrection as it did not exist in this time ${ }^{11}$.

\section{Rewritten Jonah in the OT and in Jewish Literature}

\section{Jonah in the OT}

Apart from the Book of Jonah the prophet is only mentioned in 2 Kings 14:25 as a son of the prophet Amittai from Gathheper. In the Hebrew OT, Jonah indeed is a minor prophet who is mentioned merely in 2 Kings.

The second reference from the deuterocanonical writings is uncertain in terms of textual criticism. Tobit 14:4.8 reveals Tobit's final consideration to go to Media because Nineveh will fully be overthrown. It seems as if Jonah played just a supporting role in the OT. This impression can be explained with the characterisation of the prophet as a type of anti-hero (in contrast to Abraham's obedience) in the book of Jonah itself.

\section{Jonah in Jewish Literature ${ }^{12}$}

In the apocryphal writings from the $1^{\text {st }}$ century $\mathrm{BC}$ until $1^{\text {st }}$ century AC Jonah plays a leading role. 4 Ezra 1:39 mentions Jonah along with other Israel leaders and minor prophets: Abraham, Isaac, Jacob, Hosea, Amos, Micah, Joel, Obadiah, Jonah etc. Thus, the three patriarchs are listed together with the Twelve Prophets with Jonah at the sixth position. 3 Macc reminds of Jonah's unharmed rescue with the prayer of Eleazar. He regards him as a descendant of Abraham and mentions him together with the three companions in Babylon and Daniel (6:2-8). Only the younger LXX and the apocryphal writings are interested in Jonah as a descendant of Abraham and leader of Israel.

The Jewish chronicler Flavius Josephus retells the Jonah narrative in his Jewish Antiquities (9.206-215). His portrayal of Jonah differs from the OT in regard to some important details. Firstly, he overemphasizes Jonah's flight on a ship and the story with the fish. Secondly, he mixes up Tarshish with Tarsus in Cilicia, the birthplace of Paul, and changes the dry land upon which Jonah is being deposited to the Black Sea. Thirdly, he underlines that Jonah was a Hebrew by nation and a prophet of God. Fourthly, he distinguishes between a whale and large fish. Fifthly, he portrays Jonah as a prophet confessing his sins,

11 Cf. U. Simon, Jona. Ein jüdischer Kommentar (SBS, 157), Stuttgart, Katholisches Bibelwerk, 1994; H.J. OpgenRhein, Jonapsalm und Jonabuch. Sprachgestalt, Entstehungsgeschichte und Kontextbedeutung von Jona 2 (SBB, 38), Stuttgart, Katholisches Bibelwerk, 1997; Ruhe-Glatt, Das Zeichen des Jona, pp. 41-56.

12 E. Ben Zvi, Signs of Jonah: Reading and Rereading in Ancient Yahud (JSOTSup, 367), Sheffield, Sheffield Academic Press, 2003. 
prophesying in Nineveh and returning. Sixthly, the Jonah story is embedded in Israel's history insofar as he should have promised wars and expeditions of Israel's leaders. Seventhly, he proclaims the loss of Asia if Nineveh will not convert. The narrative finishes with Jonah going home. In summary, Flavius Josephus stretches the first part of Jonah while shortening its second part. He portrays Jonah as a prophet who finally obeys God. His narrative lacks the parody of its original ${ }^{13}$.

Furthermore, the Jerusalem Targum Deut 30:1314 mentions Jonah. Two aspects are pointed out: 1. Jonah's descending into the depths of the sea, and 2. Jonah's proclaiming the commands of the sea. Jonah is presented as an escaping and repentance preaching prophet. The story about the fish is of marginal importance in the Jewish tradition ${ }^{15}$.

Just so sum up, the supporting role of Jonah is extended in the LXX, the deuterocanonical and early Jewish writings which were known to the NT writers. The anti-hero mutates into a leader of Israel, a descendant of Abraham and a hero who had expected God's rescue from the fish.

\section{Rewritten Jonah in the New Testament}

\section{References}

In the NT the book of Jonah appears in a completely different way than it is rewritten in the OT and Jewish writings. It is only referred to by name in the synoptic gospels (Matt 12:38-42; 16:1-4; Luke 11:29-3216). Furthermore, Mark 8:11-1317 and in John 6:22-59 (in particular v.30) mention a sign.

According to the list of "loci citati vel allegati" in Nestle-Aland's $27^{\text {th }}$ edition further allusions and quotations to the Book of Jonah can be found in the NT. They almost exclusively can be found in the gospel tradition ${ }^{18}$ :

13 Ant. 9.206-215.

14 "Neither is the law beyond the great sea, that thou shouldst say, O that we had one like Jonah the prophet, who could descend into the depths of the sea, and bring it to us, and make us hear its commands, that we may do them!"

15 Cf. U. Steffen, Jona und der Fisch: Der Mythos von Tod und Wiedergeburt, Stuttgart, Kreuz Verlag, 1982, pp. 47-61.

16 G.M. Landes, Jonah, pp. 133-163.

17 Cf. J. Swetnam, No Sign of Jonah, in Bib. 66 (1985) pp. 126-130 argues that missing a sign in Mark is part of his christology (Messiasgeheimnis). "He wishes to show that Jesus is the Son of God in a unique sense [...] Hence Mark does not invoke the resurrection as a sign of divine authentication of who Jesus was and what Jesus did" (J. Swetnam, Some signs of Jonah, in Bib. 68 [1987] pp. 74-79, p. 74).

18 Cf. the list of "loci citati vel allegati" in Nestle-Aland, $27^{\text {th }}$ edition (p. 799). 
Chart 1: Rewritten Jonah in the NT

\begin{tabular}{|c|c|c|c|c|}
\hline NT & Jonah 1 & Jonah 2 & Jonah 3 & Jonah 4 \\
\hline Matt 23:35 & v.4 & & & \\
\hline Matt 8:24; Mark 4:37 (great storm) & vv.4ff & & & \\
\hline Acts 27:19 (shipwreck) & v.5 & & & \\
\hline Rev $11: 13^{20}$ & v.9 9 & & & \\
\hline Mark 4:41 (storm on the sea) & v. 10 & & & \\
\hline John $11: 50^{21}$ & vv.12-15 & & & \\
\hline Luke 21:25 (eschatological signs) & v. 15 & & & \\
\hline Mark $4: 41$ (storm on the sea) & v. 16 & & & \\
\hline Matt $12: 40 ; 16: 4 ; 1$ Cor $15: 4$ (resurrection on third day) & & v.1 1 & & \\
\hline Matt 12:41; Luke 11:32 (sign of Jonah) & & & v.5 & \\
\hline Matt 11:21; Luke 10:13 (unrepentant cities) & & & vv. $5 f$ & \\
\hline Matt 2:10 (star of Bethlehem) $)^{22}$ & & & & v. 6 \\
\hline Matt 26:38; Mark 14:34 (Jesus praying in Gethsemane) ${ }^{23}$ & & & & v.9 \\
\hline
\end{tabular}

Some of the allusions listed up in the recent $\left(27^{\text {th }}\right)$ edition of Nestle-Aland are quite uncertain or doubtful: Matt 2:10; 23:35; 26:38; Mark 14:34; John 11:50 and Rev 11:13. Furthermore, it is noticeable that 1 Cor $15: 4$ is mentioned although the only connection to Jonah is the motive of the third day. And the very common motive of a storm on sea unambiguously cannot be derived from Jonah. The clearest link is the direct quotation in Matthew.

In particular, Jonah's escaping from his vocation and the fish swallowing him (1:4-2:1) is of interest for the NT writers. Furthermore, the conversion of the people of Nineveh in 3:5-6 is referred to in the NT. It surprises that the NT writers did not pay explicit attention to the two psalms in Jonah 1:17-2:10; 4:1-4 interrupting the narrative.

Most of the alluded verses in the NT are from Jonah chapter one. Apart from the synoptic tradition Jonah is mentioned just once in John, Acts, Rev, and 1 Cor. Thus, the Gospel of Matthew is highly relevant in regard to the reception of Jonah in the NT. Only once Jonah is directly quoted in Matt 12:40.

Finally, we have to look closer at one important aspect of the rewriting process of the OT in the NT. When NT writers quote a verse from the OT or just allude to it, they might mean the entire context. In particular, this is the fact in Matthew's gospel (e.g.: Ps 22:1 in Matt 27:46). A singular verse indicates the theological message of the entire writing.

\footnotetext{
19 Allusion is doubtful.

20 Allusion is doubtful.

21 Allusion is doubtful.

22 Allusion is doubtful.

23 Allusion is doubtful.
} 
Fulfilment quotations comment on an event and contain Christological statements. Hence, the quotation of the sign of Jonah also might point to other aspects of the complex narrative of Jonah.

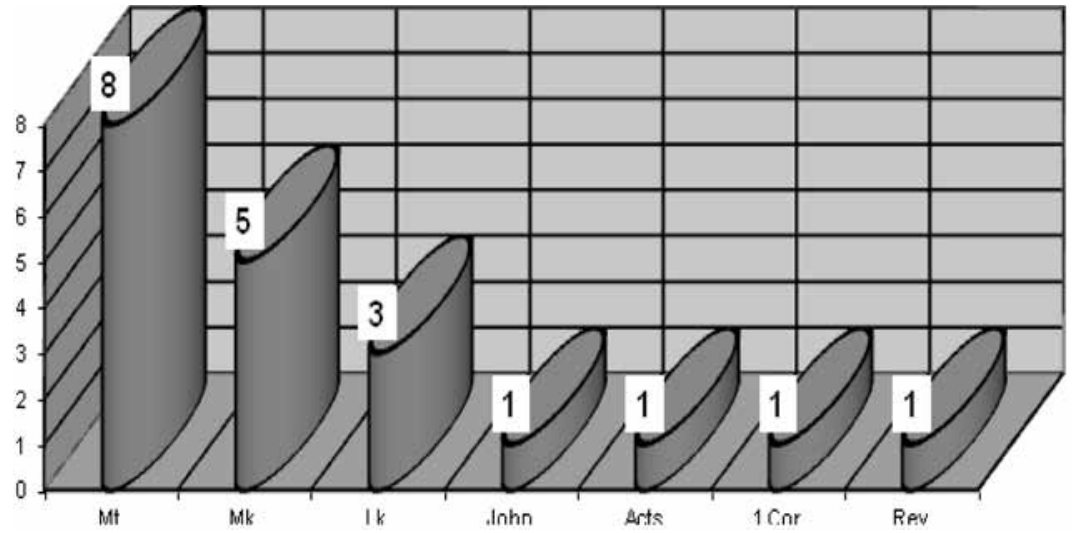

Chart 2: References to Jonah in the NT

\section{Synoptic comparison}

Synoptic reverences to Jonah's sign can be found in Matt 12:38-42; 16:1-4; and Luke 11:29-32. An indefinite sign is mentioned in Mark 8:11-13; John 6:22-59 (especially v.30). In what follows, a comparison of the four synoptic texts is presented in order to improve our view of Matthew.

Probably the oldest text version is Lk 11:30. It does not give any hint for understanding the sign. It consists of a $\kappa \alpha \theta \omega ́ \varsigma$-oü $\tau \omega \varsigma$ sentence which parallels Jonah with the Son of Man, and the men of Nineveh with this generation ${ }^{24}$.

The two other text passages (Matt 12:38) differ from the Markan Vorlage inasmuch as

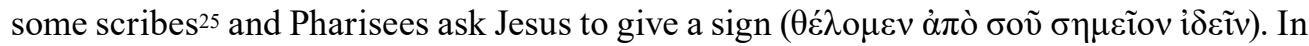
contrast to Mark the motivation of Jesus' opponents is not mentioned. Furthermore, not a sign from heaven but a sign of Jesus is demanded.

In Mark just the Pharisees are Jesus' addressees, in Matthew some scribes and Pharisees (12:38), respectively Pharisees and Sadducees (16:1). Luke does not mention opponents, but indeterminate "others" from the crowds. The atmosphere is completely different. Whilst Mark and Matthew underline a dispute between Jesus and his opponents, Luke composes a scene with Jesus teaching the crowds. A motivation for asking is just not mentioned in Matt 12:38; whilst Mk 8:11; Matt 16:1 and Luke 11:16 speak about testing Jesus $(\pi \varepsilon 1 \rho \alpha ́ \zeta \omega)$.

\footnotetext{
24 Cf. U. Luz, Das Evangelium nach Matthäus (Mt 8-17), (EKK.NT, I/2), Zürich-Braunschweig, BenzigerNeukirchen-Vluyn, Neukirchener Verlag, 2(1996), pp. 278.

25 A. Sand, Matthäus, p. 266 argues that the scribes are mentioned because of the OT quotation.
} 
Chart 3: Synoptic Comparison

\begin{tabular}{|c|c|c|c|}
\hline Aspects & Mark & Matt & Luke \\
\hline \multirow{2}{*}{$\begin{array}{c}\text { Jesus' } \\
\text { opponents }\end{array}$} & \multirow[t]{2}{*}{ 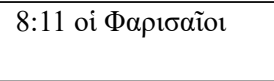 } & 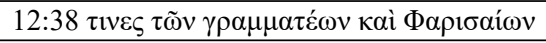 & \multirow[t]{2}{*}{ 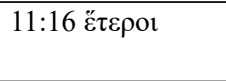 } \\
\hline & & 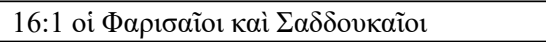 & \\
\hline \multirow[t]{2}{*}{ Motivation } & 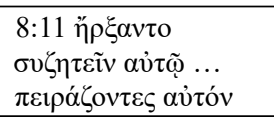 & 12:38 nihil & \multirow[t]{2}{*}{ 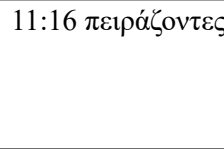 } \\
\hline & & 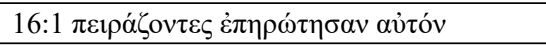 & \\
\hline \multirow[b]{2}{*}{ Sign } & \multirow{2}{*}{ 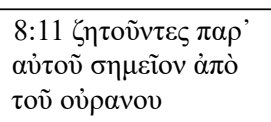 } & 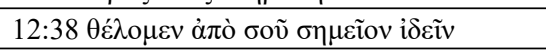 & \multirow{2}{*}{ 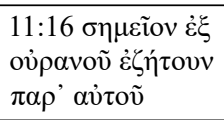 } \\
\hline & & 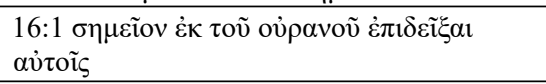 & \\
\hline \multirow[t]{2}{*}{$\begin{array}{l}\text { Jesus' } \\
\text { reaction }\end{array}$} & 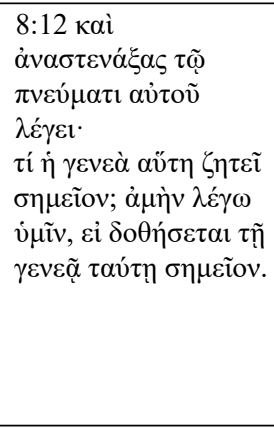 & 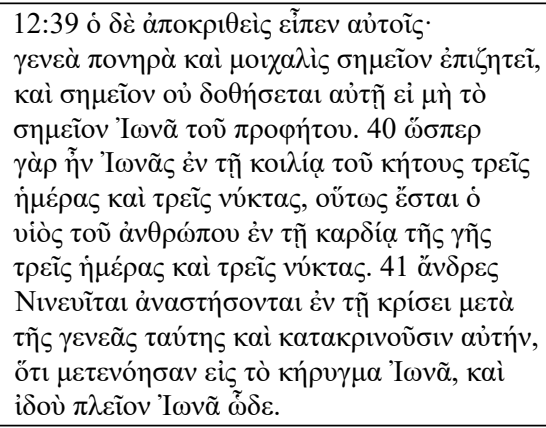 & 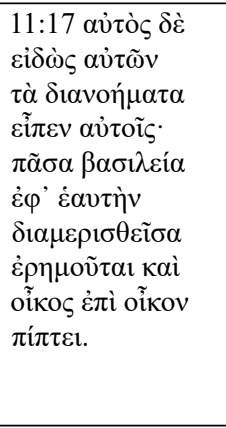 \\
\hline & & 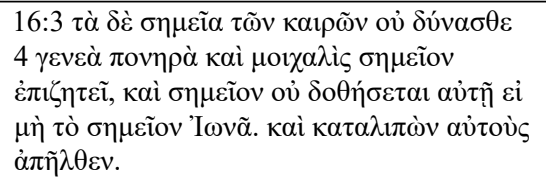 & \\
\hline
\end{tabular}

The kind of sign is an extraordinary sign from heaven (Mark 8:11; Matt 16:1; Luke 11:16) or a sign from Jesus (Matt 12:38). Jesus' interpretation of Jonah's sign differs among the three Synoptics. Whilst in Mark Jesus refuses to give a sign at all, Matt 12:38 mentions the prophet Jonah. In Matt 16:1-4 the sign of Jonah remains an enigma for Jesus' audience that is able to interpret the appearance of the sky but not the signs of the time. Luke 11:29f portrays the contemporary generation as evil. It only receives the sign of Jonah.

Luke 11:29-32 is a close parallel to Matt 12:38; Jonah is understood as a sign that leads to the repentance in Nineveh - a parallel to the queen of the South and to Jesus. Thus, the sign of Jonah compares Jesus with this prophet. Matt 16:1-4 contains a singular idea in the NT insofar as the sign of Jonah is compared with the time signals.

The demand for a sign in John 6:30 has a completely different connotation as it points to Moses. The only parallel to Matt 12:38 is the demand for a sign from Jesus ( $\tau$ í oṽv

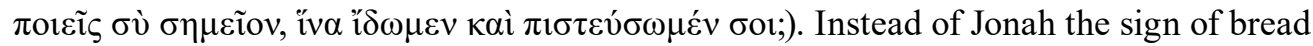
is introduced.

The most detailed reference to the Book of Jonah can be found in Matt 12:38-41 where Jonah is not only used to pronounce the result of the judgment for the contemporary generation but also to allude to Jesus' death and resurrection. It is the only direct anticipation to the death and resurrection that refers to the narrative of Jonah. 


\section{Meaning of Jonah's sign in Matt 12:38-42 and 16:1-4}

\section{Matt 12:38-42; 16:1-4}

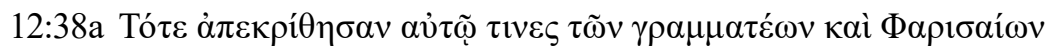

b $\lambda \dot{\varepsilon} \gamma o v \tau \varepsilon \varsigma^{\circ}$

c $\delta 1 \delta \alpha ́ \alpha \kappa \alpha \lambda \varepsilon$,

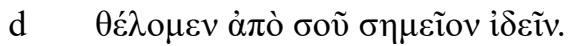

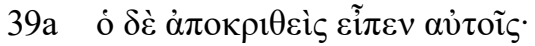

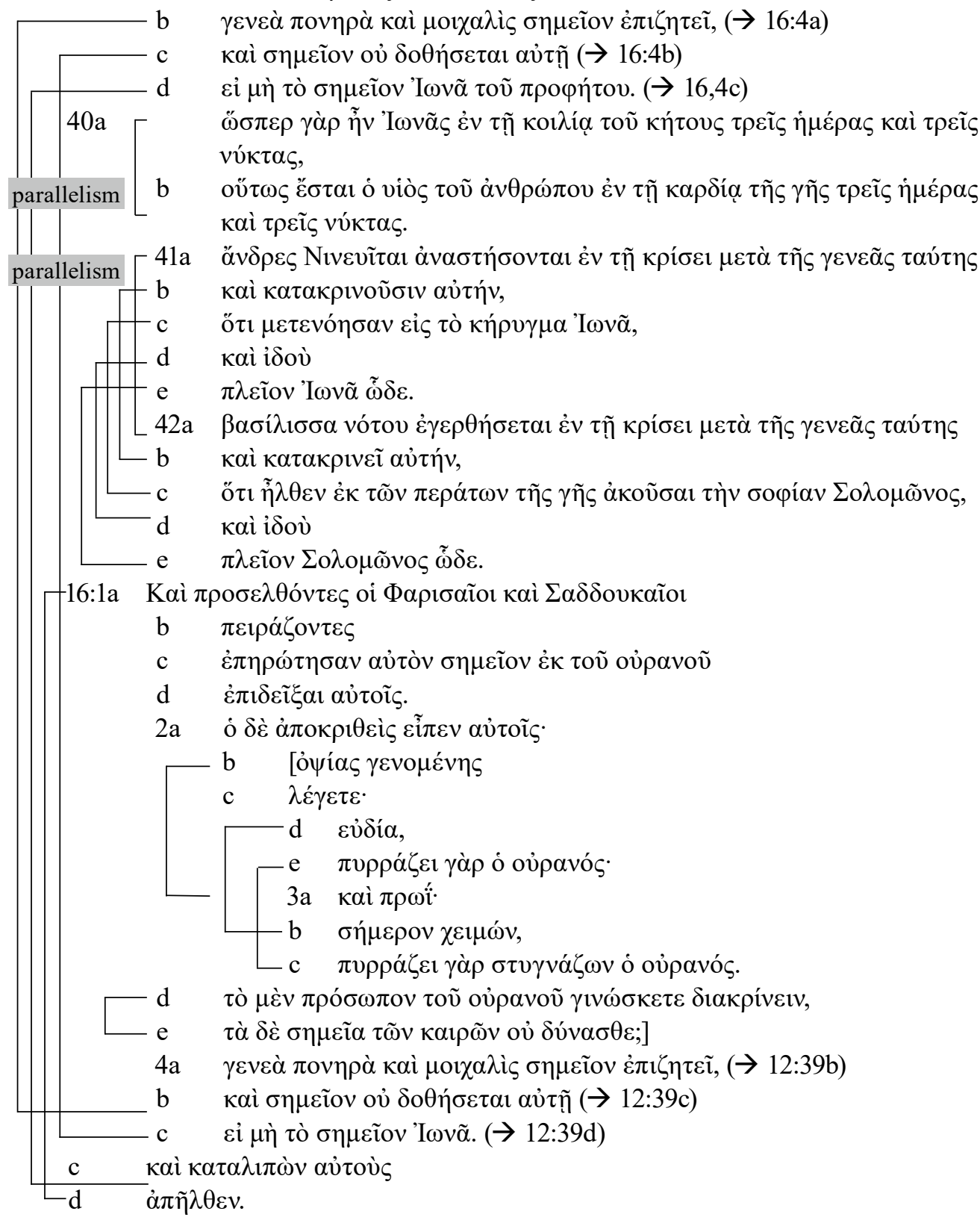




\section{Context and composition}

The sign of Jonah is placed in the context of a controversy between Jesus and the Pharisees. Matt 12:1-16:12 is a textual unit that takes place outside from Galilee. A kind of refrain runs through it: Three times it is told that Jesus withdrew from a place (12:15; $14: 13 ; 15: 21)$. Matt 13:1-53 is the third of Jesus' five major discourses in the Gospel. It forms a block within the unit 12:1-16:12 and is framed by two narrative blocks (12:1-50;

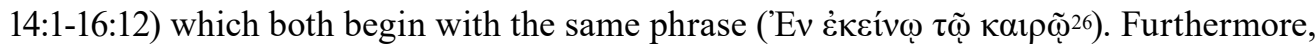
in this part Jesus tries to avoid the conflicts with the Pharisees $(12: 2.14 .24 .38 ; 15: 1.12$; 16:1.6.11-12). He calls them an evil and adulterous generation (12:39.45; 16:4), criticizes their words (12:25-45), their traditions (15:1-20), and their doctrine (16:1-12). Nevertheless, he continues to heal the sick (12:9-14:15.22; 14:14.35-36; 15:21-28.30-31).

Three arguments support the unit Matt 14:1-16:12: 1., the use of the semantic field of food; 2 ., the numerous crossings over the sea $(14: 13.22-34 ; 15: 39 ; 16: 5)$; 3., the two flashbacks in 16:1-12 (16:9: feeding of the five thousand in 14:13-21; 16:10: feeding of the four thousand in 15:29-39).

Hence, the unit Matt 12:1-16:12 has a concentric structure with Jesus' discourse of the parables in the centre, framed by two short sequences $(12: 46-50 ; 13: 53-58)$ and 12:1-45; 14:1-16:12. The sign of Jonah can be found in the frame (A-A').

A 12:1-45: Jesus' controversies with the Pharisees

B 12:46-50: Jesus' family

C 13:1-52: Discourse of the parables

B' 13:53-58: Jesus' family

A' 14:1-16:12: Jesus' controversies with the Pharisees

The sign of Jonah is introduced in v.40 in form of a synonym parallelism and a $̋ \sigma \pi \varepsilon \rho-$ oü $\tau \omega \varsigma$ sentence in 12:40a (protasis) and 12:40b (apodosis):

Chart 4: Parallels between v.40a and v.40b

\begin{tabular}{|c|c|c|}
\hline Parallels & v.40a: protasis & v.40b: apodosis \\
\hline conjunction & 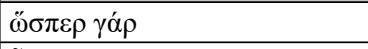 & oũ $\tau \omega \varsigma$ \\
\hline verb (tempus) & $\tilde{\eta} v$ (past) & $\ddot{\varepsilon} \sigma \tau \alpha u$ (future) \\
\hline Subject & 'I $\omega v \tilde{\alpha} \varsigma$ & ó viòs $\tau$ oṽ $\alpha \dot{\alpha} v \rho \rho \dot{\pi} \pi \mathrm{ov}$ \\
\hline Location & 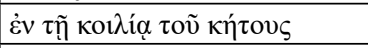 & 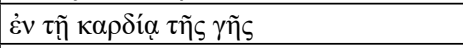 \\
\hline Time & 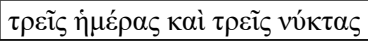 & 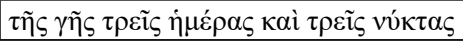 \\
\hline
\end{tabular}

The future ( $\check{\varepsilon} \sigma \tau \alpha$ ) of the Son of Man is compared with the past (imperfect $\tilde{\eta} v$ ) of Jonah. The locations are comparable insofar both are in the depth of something: either in a belly

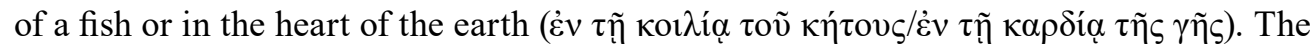
time of three days and nights is identical. As the action of the Son of Man will be in the future, its meaning is not (yet) determined. The comparison between Jonah and Son of Man functions as an anticipation and prediction of Jesus' death and resurrection in Mat-

26 The phrase only occurs in Matt 11:25; 12:1 and 14:1. 
thew's gospel. In fact it is a vaticinium ex eventu as the gospel was written after Jesus' death and resurrection.

In v.40 Jesus prophecies his death and resurrection with the comparison to the Jonah story: His death is explicitly expressed with the time of three days and nights and the location of the heart of the earth. The idea of his resurrection is implicitly expressed by the rescue of Jonah (2:11) and the use of the Christological title "Son of Man". Apart from the daily life of the Son of Man, Matthew underlines two characteristic aspects: the suffering and the judging Son of Man. Thus, the future tense ( $\left.\varepsilon_{\sigma} \sigma \alpha 1\right)$, the subject (Son of Man), and the biblical idea of rescue after three days point to the idea of resurrection. Whilst God rescued Jonah after three days and nights in the belly of the fish, he will rescue his Son after three days and nights in the heart of the earth.

Further parallel structures can be detected in vv.41-42:

Chart 5: Parallels between v.41 and v.42

\begin{tabular}{|c|c|}
\hline v.41 & v.42 \\
\hline 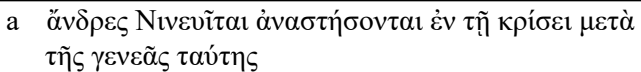 & 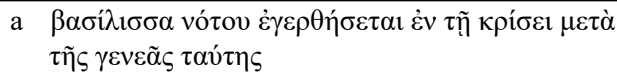 \\
\hline 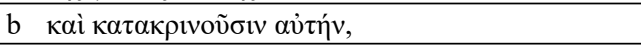 & 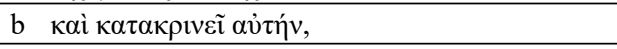 \\
\hline 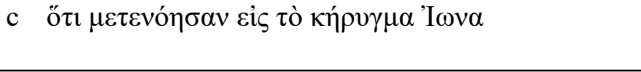 & 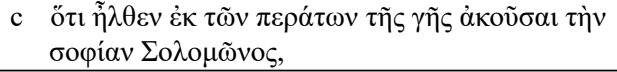 \\
\hline d Kaì íoú & $\mathrm{d} \quad$ Kaì íoov́ \\
\hline e $\pi \lambda \varepsilon \tilde{c} v^{\prime} \mathrm{\prime} \omega v \tilde{\alpha} \tilde{\omega} \delta \varepsilon$. & e $\pi \lambda \varepsilon \tilde{i} о \nu \Sigma o \lambda o \mu \tilde{\omega} v o \varsigma \tilde{\omega} \delta \varepsilon$. \\
\hline
\end{tabular}

The men of Nineveh are compared with the queen of the South (1 Kings 10:1-13). The men of Nineveh repented at Jonah's preaching and the queen of South heard Solomon's wisdom, but the contemporary generation did not repent at Jesus' preaching. Therefore, both (the men of Nineveh and the queen of the South) will arise at the judgment with this generation and condemn it. The Jesus event is characterised as something greater than Jonah respectively Solomon. The two sayings contrast the OT positive response to God with the negative response to Jesus.

$$
\begin{array}{lllll}
\text { men of Niniveh } & \rightarrow & \text { repent at Jonah's preaching } & \rightarrow & \text { arise at judgment } \\
\text { queen of South } & \rightarrow & \text { hear Solomon's wisdom } & \rightarrow & \text { arise at judgment }
\end{array}
$$

The connection of Jonah with the queen of the South and the judgment by Jonah's addressees is singular in the entire Jewish-Christian writings. It occurs only in Matt 12:39-41 and Luke 11:29-32.

Two different interpretations of the sign of Jonah are closely connected in Matt 12:4042. On the one hand the divine rescue of Jonah after having been swallowed by the fish as an answer to the Matthean community, on the other hand the judgment as an appropriate response to Jesus' opponents. Matt 12:40-42 is part of the longer unit 12:1-16:12 in which conflicts with the Pharisees (12:2.14.24.38; 15:1.12; 16:1.6.11-12) and the healing of the sick (12:9-14:15.22; 14:14.35-36; 15:21-28.30-31) are the two major topics. The two aspects of the sign of Jonah (rescue, judgment) respond to the two different addressees: Rescue is promised to the sick; judgment is announced to Jesus' opponents. 
Both text segments (12:39-42 // 16:1-4) are not merely linked in terms of semantics but also frame the segment 12:43-15:39 in form of a chiasm. The two texts are typical Matthean „duplicates” that frame a longer part of Matthew's gospel. The text segments framed by 12:39-42 and 16:1-4 are a mixture of narratives, parables, miracles and Jesus' sayings.

Chart 6: Comparison of the duplicates

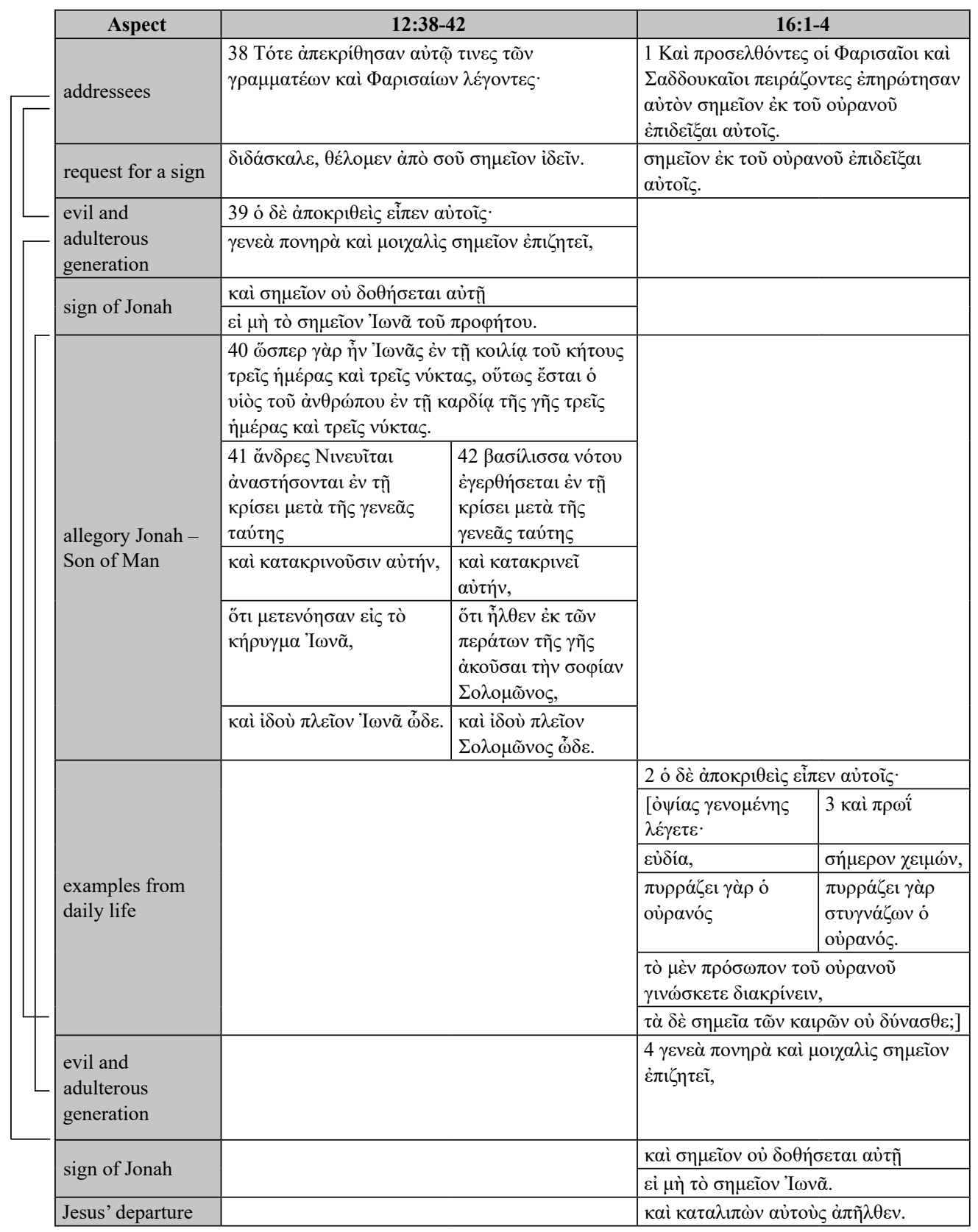


Apart from the parallels, the variations in Matt 16:1-4 are most interesting. Only Matt 12:38-42 indicates a meaning of the sign of Jonah, the second text (Matt 16:1-4) keeps silent about it. Both text segments contain the following four elements: 1. addressees; 2. request for a sign; 3. portrayal of the current generation; 4. sign of Jonah. Matt 12:38-42 is longer than 16:1-4 because the Jonah-Jesus-typology is left out in vv.40-42. The second text amends examples from daily life after the request for a sign.

The sign of Jonah is connected with Jonah's stay in the belly of the fish in Matt 12:3842. The second text (Matt 16:3) links it with the signs of the times ( $\tau \grave{\alpha} \delta \dot{\varepsilon} \sigma \eta \mu \varepsilon \tilde{\alpha} \alpha \tau \tilde{\omega} v$ $\kappa \alpha \iota \tilde{\omega} v)$. This expression comes from the OT creation narrative and late deuterocanonical wisdom theology (Gen 1:14; Wis 8:8; Sir 43:6). The appearances of the sky are understood as signs to detect the kalpós. Jesus' reproaches his opponents for just looking at the surface of things and for being unable to understand the deeper meaning of the sign. The major difference between the two texts is the interpretation of the Jonah sign. Either it is incorporated into a typology which portrays Jesus as greater than the prophet Jonah, or it is part of Jesus' prophetic criticism at the misinterpretation of signs by the current generation. In any case, the sign of Jonah functions as part of Matthew's Christology and his penitential sermon for his community.

\section{Jesus' addressees}

Jesus addressees in 12:38 are some of the scribes and Pharisees. The combination of both groups is characteristic for Matthew's gospel (5:20; 12:38; 15:1; 23:2.13.15.23.25.27.29), especially in chapter 23 . Only in 12:38 Matthew distinguishes and speaks about $\tau \imath v \varepsilon \varsigma \tau \tilde{\omega} v$

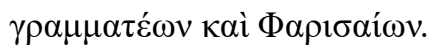

In Matt 16:1 Pharisees and Sadducees are mentioned as addressees. This combination just occurs in Matt 3:7; 16:1.6.11-12; $22: 34$ (and in Acts 23:6-8). The Pharisees have a hidden agenda while asking Jesus for a sign.

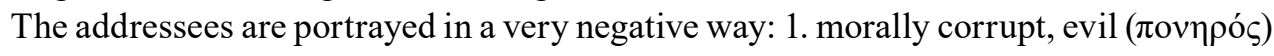
and adulterous $\left(\mu \mathrm{o} \chi \alpha \lambda \lambda_{i}\right)^{27}{ }^{27} 2$. the men of Nineveh will condemn this generation as they did not repent at Jesus' preaching; 3. the queen of the South will condemn this generation as they did not hear the wisdom of Jesus. Thus, the addressees are criticized for not repenting and not listening to the wisdom of Jesus.

On the level of the narrative both text segments are addressed to Jesus' opponents. As the gospel is written for a community the enemies of the Matthean church are meant.

\section{Motivation for demanding a sign}

The first text segment does not explicitly mention a motivation. The context is a mixture of healings, exorcisms and conflict stories. Therefore we can doubt that their intentions were honourable. 16:1 reveals the intention explicitly: Pharasees and Sadducees are tempting Jesus.

27 This means in a real sense sexual misbehaviour and in metaphorical sense unfaithfulness in relation to God. 
Compared with other conflict stories it can be expected that Jesus' answer will be most diplomatic and cautious. He is careful not to be manipulated by his opponents. Therefore he answers with a riddle which is difficult to understand.

Whilst his opponents expect him executing a supernatural sign that authorises him as the Messiah he answers with a riddle that does not fulfil their expectations. Both are talking at cross purposes. A misunderstanding of the sign of Jonah is intended in Matthew's gospel.

\section{Understanding of $\sigma \eta \mu \varepsilon \tilde{o}$ v in Matt}

Jesus' speech opens with the enigma of Jonah's sign:

39 a An evil and adulterous generation seeks for a sign;

$b \quad$ but no sign shall be given to it

c except the sign of the prophet Jonah.

The meaning of this sign ${ }^{28}$ is discussed among scholars. Three opinions predominate among scholars 29 :

a) John the Baptist is the sign of Jonah as the name Jonah is the abbreviation of John and as Jesus proclaimed the Baptist as the Elijah redivivus ${ }^{30}$. This assumption is quite uncertain and not convincing.

b) Older exegetical publications favour the idea that Jonah's sign is identical with his penitential sermon. This hypothesis is not convincing since $\sigma \eta \mu \varepsilon i o v$ belongs to the semantic field of non-verbal communication. It indicates an event with a special mean-

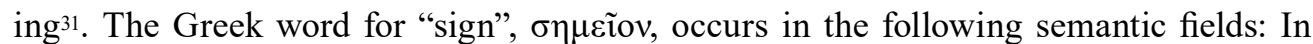
Mark's Gospel the Pharisees argue with Jesus and demand a sign from heaven (8:11

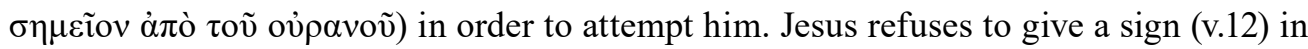
order not to be manipulated by his enemies. Matt 16:1 is the closest parallel to Mark 8:11. The Pharisees along with the Sadducees - an addition of Matthew - and their motivation (tempting Jesus) are mentioned just as the sign of heaven.

In John's gospel the miracles (possibly including the resurrection) are called $\sigma \eta \mu \varepsilon \tilde{o}$, in the synoptic tradition they are called $\delta v ́ v \alpha \mu \iota$. Furthermore, $\sigma \eta \mu \varepsilon i ̃ o v$ is never linked with a sermon but always with a (visible) divine intervention or confirmation of divine

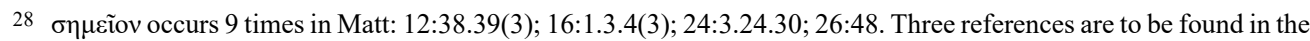
apocalyptic speech $(24: 3.24 .30)$; they are closely connected with the two text segments $(12: 38.39$ [3]; $16: 1.3 .4[3])$ on the sign of Jonah. The last one is the betrayer's sign. In short: $\sigma \eta \mu \varepsilon i \tau o v$ indicates non-verbal communication and signals eschatological aspects.

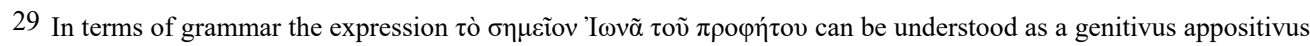
/ epexegeticus (Jonah is the sign himself) or as a genitivus subiectivus (a sign done by Jonah), or as genitivus obiectivus (sign visible at Jonah). Cf. Luz, Matthäus, pp. 278-280; K. Huber, Zeichen, pp. 82-86.

30 Cf. U.-K. Plisch, Was ist „, das Zeichen des Jona “?, in H.-G. Bethge - S. Emmel - K.L. King - I. Schletterer (eds.), For the Children, Perfect Instruction: Studies in Honor of Hans-Martin Schenke on the Occasion of the Berliner Arbeitskreis für koptisch-gnostische Schriften's Thirties Year (Nag Hammadi Studies, 54), Leiden - Boston, Brill, 2002, pp. 399-409, p. 408: „Aus den angeführten Möglichkeiten ergibt sich [...] die Möglichkeit, [...] einen Verweis Jesu auf seinen Zeitgenossen Johannes und dessen Bußpredigt zu erblicken“.

31 Cf. J.P. Louw - E.A. Nida, A Greek English Lexicon of the New Testament Based on Semantic Domains. 2 Volumes, New York, NY, United Bible Societies, 3(1989). 
salvation (e.g. a sign of covenant as the miracles of the Exodus). The term $\sigma \eta \mu \varepsilon i$ ov very often is connected with $\tau \dot{\varepsilon} \rho \alpha \varsigma$ (46 out of 197 reverences of $\sigma \eta \mu \varepsilon i ̃ o v$ in the Greek Bible). Even the few prophetic writings that use $\sigma \eta \mu \varepsilon \tilde{i}$ v (Isaiah, Jeremiah, Baruch, Ezekiel) understand it in this way. The OT signs only rarely refer to supernatural or miraculous dimensions. Quite the reverse, they serve to confirm an action of the word of God.

Matthew uses $\sigma \eta \mu \varepsilon i ̃ o v$ thirteen times $(12: 38.39[3 \mathrm{x}] ; 16: 1.3 .4[3 \mathrm{x}] ; 24: 3.24 .30 ; 26: 48)$, nine times in the context of the sign of Jonah. Apart from these references, $\sigma \eta \mu \varepsilon i ̃ o v$ is used in the eschatological discourse to indicate the very end of times (24:3.24.30). Furthermore, $\sigma \eta \mu \varepsilon \tilde{i}$ v is used for the kiss of Judas (26:48). Although $\sigma \eta \mu \varepsilon i \tilde{o v}$ has a future aspect in Matthew's gospel, it does not necessarily have a supernatural dimension.

c) The most persuading theory is that Jonah's rescue from the fish is regarded as a sign in Matt 12:38. Jesus' speech continues in Matt 12:40 with a tertium comparationis ${ }^{32}$ :

40 For as Jonah was three days and three nights in the belly of the fish,

$b \quad$ so will the Son of man be three days and three nights in the heart of the earth.

The motifs of the Son of Man, a Christological title, the duration of three days and nights, and the stay in the belly of the fish or rather in the heart of the earth with Jonah are comparable. The expression $\dot{\varepsilon} v \tau \tilde{\eta} \kappa \alpha \rho \delta i \underline{\alpha} \tau \tilde{\eta} \varsigma \gamma \tilde{\eta} \varsigma$ is singular in the entire Bible. As it is another image it is difficult to use it for the interpretation of the belly of the fish.

Chart 7: Jonah - Son of Man

\begin{tabular}{|l|l|}
\hline \multicolumn{1}{|c|}{ Jonah } & \multicolumn{1}{c|}{ Son of Man } \\
\hline three days and three nights & three days and three nights \\
\hline in the belly of the fish & In the heart of the earth \\
\hline
\end{tabular}

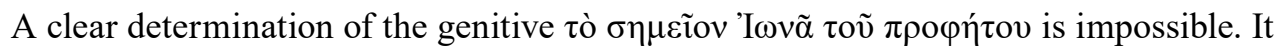
grammatically can be interpreted as a genitivus appositivus / epexegeticus (Jonah is the sign himself), or as a genitivus subiectivus (a sign done by Jonah), or as genitivus obiectivus (sign visible at Jonah). The sign of Jonah can be interpreted in two different ways: 1., Jesus himself is the sign. 2., Jesus' preaching repentance is the sign.

\section{Meaning of three days and three nights}

The time of three days and three nights ${ }^{33}$ is common in biblical writings. It stands for a crisis and/or a change after a crisis.

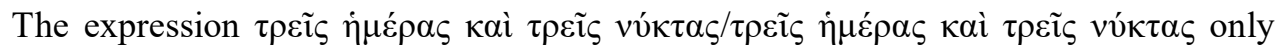
occurs three times in the OT and once in the NT (as a rewriting of Jonah). The idea is

32 Cf. J. Jeremias, 'I $\omega v \tilde{\alpha} \varsigma$, pp. 410-413.

33 Cf. K. Lehmann, Auferweckt am dritten Tag nach der Schrift: Früheste Christologie, Bekenntnisbildung und Schriftauslegung im Lichte von 1 Kor. 15, 3-5 (QD, 38), Freiburg, Herder, 2(1969) (= digital version edited by M. Kinnen - A. Raffelt 2004). 
either applied to eating and drinking in 1 Sam 30:12 ("And when he had eaten, his spirit revived; for he had not eaten bread or drunk water for three days and three nights.") and Esth 4:16 ("Go, gather all the Jews to be found in Susa, and hold a fast on my behalf, and neither eat nor drink for three days, night or day.") or connected with being in the belly of the fish in Jonah 2:1 and Matt 12:40. It seems to imply that the duration of three days and three nights involves a decision on death or life. In particular, 1 Sam 30:12 emphasizes restoration after this period.

Three days are mentioned more often in the Bible ${ }^{34}$. They are connected with a journey through the desert/wilderness; stay in Jerusalem; encounter with God; plagues; repentance; succession; riddle; and war event. ${ }^{35}$

In the NT the duration of three days has other connotations. Both miracles of feeding the crowds take place on the third day (Matt 15:32; Mark 8:2). Finding the twelve year old Jesus in the temple also takes place on the third day (Luke 2:46). This narrative is closely connected with the walk to Emmaus (24:1.13). The eucharist and Jesus' resurrection are always connected with the third day - not after three days ${ }^{36}$. Three days mean a turning point after a crisis (cf. Acts 9:9) ${ }^{37}$.

There might be a close connection between Matt 12:38-42 to the temple word of Jesus in John 2:20 that might elucidate Jonah's sign:

34 Gen 30:36 (journey of three days); 40:12.13.18.19; 42:17 (Joseph: dream interpretation); Exod 3:18 (journey of three days); 5:3 (journey of three days); 8:23 (journey of three days); 10:22.23 (plague: darkness); 15:22 (journey in the desert without water); 19:15 (preparation for the encounter with YHWH); Num 10:33 (journey with the ark of the covenant); 33:8 (journey in the desert); Josh1:11 (passing the Jordan within 3 days); 2:16.22 (spies sent to Jericho); 3:2 (Israel crossing the Jordan); 9:16 (covenant after 3 days); 14:14 (riddle); 19:4 (Levite's concubine); 2 Sam 20:4 (rebellion of Sheba); 2 Sam 24:13 (three days of pestilence); 1 Kings 12:5 (northern tribes secede); 2 Kings 2:17 (Elisha succeeds Elijah); 1 Chr 12:39 (David's army in Hebron); 21:12 (pestilence); 10:5 (revolt); 20:25 (plunder); Ezra 8:15 (camp); 8:32 (3 days in Jerusalem); 8:41 (leaders return); 10:8.9 (assembly in Jerusalem within 3 days); Neh 2:11 (Nehemia in Jerusalem); Jdt 2:21 (journey); 12:7 (Judith in the camp); 1 Macc 5:24 (journey through the wilderness); 10:34 (no taxes for Jews 3 days for and after a feast); 2 Macc 5:14 (destruction of inhabitants); 13:12 (weeping and fasting); Jonah 2:1 (fish); 3:3 (3 days journey through Nineveh); 3:4 LXX (three days until the destruction of Nineveh).

35 Journey (Gen 30:36; Exod 3:18; 5:3; 8:23; 15:22; Num 10:33; 33:8; Jdt 2:21; 1 Macc 5:24; Jonah 3:3); crossing the Jordan, sending of spies (Josh 1:11; 3:2; 2:16.22); staying in Jerusalem (Ezra 8:32; 10:8.9; Neh 2:11; 1 Chr 12:39); encountering with YHWH, covenant (Exod 19:15; Josh 9:16); plagues (10:22.23: darkness; 21:12: pestilence; 2 Sam 24:13: pestilence); repentance (2 Macc 13:12: weeping and fasting; Jonah 3:4 LXX); succession (2 Kings 2:17); riddle / dream (Gen 40:12.13.18.19; 42:17; Josh 14:14); war (2 Sam 20:4; 1 Kings 12:5; 1 Chr 10:5; 20:25; Ezra 8:15; 8:41; Jdt 12:7).

36 A. Sand, Matthäus, p. 267 concludes that the sign of Jonah is applied to Jesus' burial.

37 Cf. N.H. Young, The Use of Sunday for Meetings of Believers in the New Testament: A Response, in NovT 45 (2003) 111-122, pp. 120-121, points to the vague time references. 
Chart 8: Comparison Matt 12:38-40 - John 2:18-22

\begin{tabular}{|c|c|}
\hline$: 38-40$ & John 2:20 \\
\hline 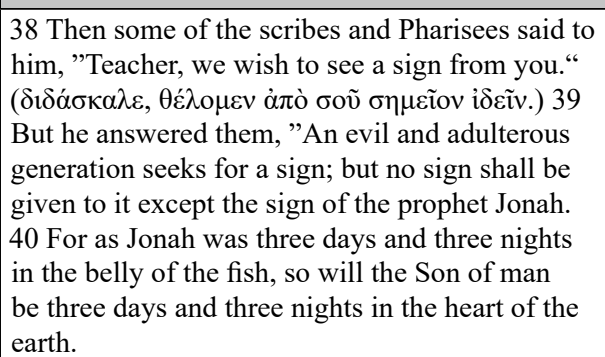 & 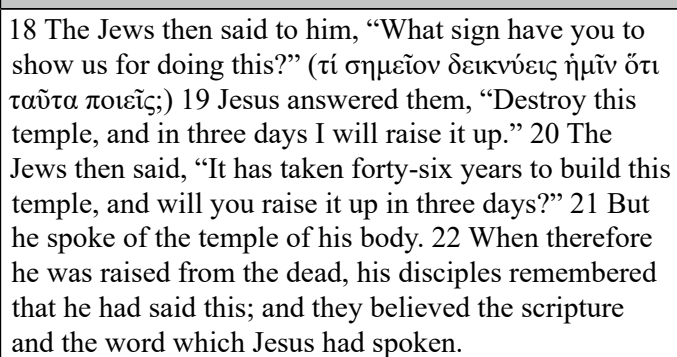 \\
\hline
\end{tabular}

Both text segments contain scenes that reflect on a conflict between Jesus and his opponents (Matthew: scribes and Pharisees; John: Jews) demanding a sign from Jesus. A second parallel is the negative assessment of Jesus' addressees by the narrators (Matt

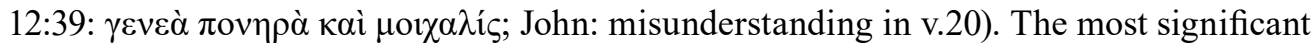
agreement is the time of three days in combination with the stay in the fish (Jonah) and with the temple (John). Both texts do not only mention the three days but also indicate the meaning of it:

Chart 9: Idea of resurrection Matthew - John

\begin{tabular}{|l|l|l|}
\hline \multicolumn{1}{|c|}{ Aspect } & \multicolumn{1}{|c|}{ Matt } & \multicolumn{1}{c|}{ John } \\
\hline Image & Jonah: 3 days and 3 nights in the belly of the fish & $\begin{array}{l}\text { 3 days for destructing the temple } \\
\text { 3 days for reconstructing the temple }\end{array}$ \\
\hline Interpretation & Jesus: 3 days and 3 nights in the heart of the earth & Jesus = temple \\
\hline Meaning & Resurrection & Resurrection \\
\hline
\end{tabular}

Both texts interpret the duration of three days likewise. Both images (fish, temple) are used to express destruction and reconstruction, which are also crucial in Jesus' life (passion, resurrection). The riddle in John 2:20 can illuminate the understanding of Matt 12:38-42.

\section{Jonah and the Son of Man}

Matt 12:41-42 is a characteristic Matthean saying about the Son of Man. The Christological title Son of Man is preferred in Matthew's gospel $(8: 20 ; 9: 6 ; 10: 23 ; 11: 19 ; 12: 8.32 .40$; $13: 37.41 ; 16: 13 ; 16: 27.28 ; 17: 9.12 .22 ; 19: 28 ; 20: 18.28 ; 24: 27.30 .37 .39 .44 ; 25: 31 ; 26: 2$; 26:24.45.64). Three different topics are connected with the title: suffering (12:40; 17:9; $20: 18.28$; 26:2.45), judging (10:23; 12:32; 13:41; 16:27.28; 19:28; 24:27.30.37.39.44; 25:31; 26:24.64), and the daily life of the Son of Man $(8: 20 ; 9: 6 ; 11: 19 ; 12: 8 ; 13: 37 ; 16: 13)$. Most of the titles are connected with Jesus' role in the final judgment.

The saying in 12:40 is assigned to two categories: to the suffering Son of Man and the judging Son of Man. The Jesus' prediction about the sign of Jonah in Matt 12:40 connects two aspects with each other: On the one hand hope for resurrection; and on the other hand 
the final judgment for those who do not believe in the Son of Man. Both theologoumena belong together as they deal with the redemption of men.

\section{Summary}

The questions we dealt with were: What did Matthew mean with the sign of Jonah? Did Matt understand it in terms of resurrection? And if so, did he follow examples of the past? Why did he mention the sign of Jonah in this particular context of his composition?

Jonah is quoted by Matthew's Jesus to criticize the idea of an available God who gives a sign from heaven as expected. Just as the book of Jonah condemns doctrinal theology the two text segments Matt 12:38-42 and 16:1-4 reveal unrealistic expectations of Jesus' opponents. Jesus' answer exceeds all expectations in regard to a sign from heaven and to God. A supernatural visible miracle is not the response, but the hope for a faithful God and for the final resurrection. The sign of God given by Jesus is a criticism against fixed theological doctrines.

The sign of Jonah will remain an enigma in Matthew's gospel. The fact that it cannot be unequivocally solved is a component of Matthew's theology and narrative. Preconditions to understand the sign of Jonah in terms of Jesus' death and resurrection are repentance and belief. Jesus' opponents demand a sign and expect a supra-natural sign. They were confronted with a riddle which could be understood by his followers, respectively the Matthean community. It necessarily must be misunderstood by Jesus' enemies and the community's opponents as they had other expectations and a hidden agenda. Furthermore, it might reflect a conflict within the Matthean community: Jews reject Jesus whilst Gentiles follow him (mission to Israel in 10:6; 15:24 - but universal mission: 28:16-20). The sign of Jonah is directed to this particular and difficult situation of the Matthean community and their opponents.

In the context of the sign of Jonah Matthew develops a Jonah-Jesus-typology ${ }^{38}$ and a Solomon-Jesus-typology: Jesus is greater than the two of them. Both are regarded as precedents for Jesus' death and resurrection, his penitential sermon and his wisdom. Furthermore, the OT figures contrast the positive response of Israel with the negative response of Jesus' opponents. Insofar the controversy story presents answers to the Jewish-Christian community of Matthew.

\section{Bibliography}

Adam, A.K.M., The Sign of Jonah: A Fish-Eye View, "Semeia" 51(1990), p. 177-191.

Ben Zvi E., Signs of Jonah: Reading and Rereading in Ancient Yahud (JSOTSup, 367), Sheffield, Sheffield Academic Press, 2003.

Chow S., The Sign of Jonah Reconsidered: A Study of its Meaning in the Gospel Traditions (ConBNT, 27), Stockholm, Almqvist \& Wiksell, 1995.

Edwards R.A., The Sign of Jonah in the Theology of the Evangelists and Q (SBT, 2/18), London, SCM, 1971.

38 Cf. D.J. Harrington, The Gospel of Matthew (SP, 1), Collegeville, MN, Liturgical Press 2(2007). 
Fales E., Taming the Tehom: The Sign of Jonah in Matthew, in: R.M. Price - J.J. Lowder (eds.),

The Empty Tomb: Jesus Beyond the Grave, Amherst, N.Y., Prometheus Books, 2005, p. 307-348.

Fiedler P., Das Matthäusevangelium (ThKNT, 1), Stuttgart, Kohlhammer 2006.

Fuchs A., Das Zeichen des Jona: Vom Rückfall, SNTSU 19(1994), p. 131-160.

Harrington D.J., The Gospel of Matthew (SP, 1), Collegeville, MN, Liturgical Press 2(2007).

Huber K., ,Zeichen des Jona“ und „,mehr als Jona“: Die Gestalt des Jona im Neuen Testament und ihr Beitrag zur bibeltheologischen Fragestellung, PzB 7,2 (1998), p. 77-94.

Jeremias, J., 'I $\omega v \tilde{\alpha} \varsigma$, ThWNT 3(1938), p. 410-413.

Jeremias J., 'I $\omega v \tilde{\alpha} \varsigma$, p. 410-413.

Landes G.M., Jonah in Luke: The Hebrew Bible Background to the Interpretation of the 'Sign of Jonah' Pericope in Luke 11.29-32, in: R.D. Weis - D.M. Carr (eds.), A Gift of God in Due Season: Essays on Scripture and Community in Honor of James A. Sanders (JSOTSup, 225), Sheffield, JSOT-Press, 1996, p. 133-163.

Lehmann K., Auferweckt am dritten Tag nach der Schrift: Früheste Christologie, Bekenntnisbildung und Schriftauslegung im Lichte von 1 Kor. 15, 3-5 (QD, 38), Freiburg, Herder, 2(1969) (= digital version edited by M. Kinnen - A. Raffelt 2004).

Louw J.P. -Nida E.A., A Greek English Lexicon of the New Testament Based on Semantic Domains. 2 Volumes, New York, NY, United Bible Societies, 3(1989).

Luz U., Das Evangelium nach Matthäus (Mt 8-17), (EKK.NT, I/2), Zürich - Braunschweig, Benziger - Neukirchen-Vluyn, Neukirchener Verlag, 2(1996).

Opgen-Rhein H.J., Jonapsalm und Jonabuch. Sprachgestalt, Entstehungsgeschichte und Kontextbedeutung von Jona 2 (SBB, 38), Stuttgart, Katholisches Bibelwerk, 1997.

Plisch U.-K., Was ist „,das Zeichen des Jona“?, in: H.-G. Bethge - s. Emmel - K.L. King I. Schletterer (eds.), For the Children, Perfect Instruction: Studies in Honor of HansMartin Schenke on the Occasion of the Berliner Arbeitskreis für koptisch-gnostische Schriften's Thirties Year (Nag Hammadi Studies, 54), Leiden - Boston, Brill, 2002, p. 399-409.

Reed J.L., The Sign of Jonah (Q 11:29-32) and other Epic Traditions Q, in: E.A. Castelli H. Taussig (Eds.), Reimaging Christian Origins, Valley Forge, Pa., Trinity Press, 1996, p. 130-143.

Rudman, D., The Sign of Jonah, ExpTim 115(2004), p. 325-328.

Ruhe-Glatt C., Das Zeichen des Jona, PzB 10(2001), p. 41-56, p. 54.

Sand A., Das Evangelium nach Matthäus (RNT), Regensburg, Pustet, 1986, p. 265-267.

Schmitt G., Das Zeichen des Jona, in: ZNW 69(1978), p. 123-129.

Seidelin P., Das Jonaszeichen, ST 5(1951), p. 119-131.

Simon U., Jona. Ein jüdischer Kommentar (SBS,157), Stuttgart, Katholisches Bibelwerk, 1994.

Soulen R.K., The Sign of Jonah, ThTo 65,3(2008), p. 331-343.

Steffen U., Jona und der Fisch: Der Mythos von Tod und Wiedergeburt, Stuttgart, Kreuz Verlag, 1982.

Swetnam J., No Sign of Jonah, Bib. 66(1985), p. 126-130.

Swetnam J., Some signs of Jonah, Bib. 68(1987), p. 74-79. 
Vögtle A., Der Spruch vom Jonazeichen, in: Id., Evangelium und die Evangelien. Beiträge zur Evangelienforschung (KBANT), Düsseldorf, Patmos, 1971, p. 103-136.

Young N.H., ,, The Use of Sunday for Meetings of Believers in the New Testament”: A Response, NovT 45(2003), p. 111-122.

\section{Summary}

The article deals with particular texts that are not limited to the resurrection narratives in Matt 28. In what follows we will have a close look at Matthew's understanding of Jonah's sign. What did he mean with the sign of Jonah? Did Matthew understand it in terms of resurrection? And if so, did he follow examples of the past? Why did he mention the sign of Jonah in this particular context of his composition?

Keywords: Jonah, rewritten Bible, OT and Jewish literature, syn comparison, resurrection,

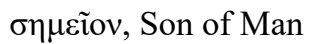

\section{Streszczenie}

\section{ZNACZENIE I FUNKCJA ZNAKU JONASZA W EWANGELII ŚW. MATEUSZA 12:38-42 I 16:1-4}

Artykuł dotyczy poszczególnych tekstów, które nie są ograniczone jedynie do opisu zmartwychwstania w Ewangelii wg św. Mateusza 28. W dalszej części zobaczymy, jak św. Mateusz rozumie znak Jonasza. Co miał na myśli, mówiąc o znaku Jonasza? Czy rozumiał, że chodzi o zmartwychwstanie? A jeśli tak, to czy podążał za przykładami z przeszłości? Dlaczego wspomniał o znaku Jonasza w tym konkretnym kontekście?

Słowa kluczowe: Jonasz, ponownie napisana Biblia, Stary Testament i literatura żydowska,

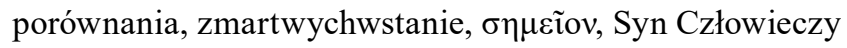

